\title{
Population dynamics of the marine planktonic ciliate Strombidinopsis multiauris: its potential to control phytoplankton blooms
}

\author{
David J. S. Montagnes ${ }^{1, *}$, Evelyn J. Lessard ${ }^{2}$ \\ ${ }^{1}$ Port Erin Marine Laboratory, School of Biological Sciences, University of Liverpool, Port Erin, \\ Isle of Man IM9 6JA, British Isles \\ ${ }^{2}$ University of Washington, School of Oceanography, Box 357940, Seattle, Washington 98195-7940, USA
}

\begin{abstract}
The growth, grazing, and cell volume of Strombidinopsis multiauris, a large $(-100 \mu \mathrm{m})$ coastal planktonic ciliate, is affected by food concentration and temperature. Using growth and grazing data, we modelled small-scale bloom dynamics between the ciliate and its prey. Growth experiments were conducted at $13^{\circ} \mathrm{C}$ on S. multiauris fed the $10 \mu \mathrm{m}$ dinoflagellate Gymnodinium simplex; changes in cell numbers and cell volume were monitored. Ingestion rate was measured by 3 methods (uptake of fluorescently labelled latex beads; heat-killed, fluorescently labelled $G$. simplex; and ${ }^{14} \mathrm{C}$-labelled $G$. simplex). Growth rate versus food concentration followed a rectangular hyperbolic response, with a maximum of $\mu=0.6 \mathrm{~d}^{1}$ above $10^{4}$ prey $\left.\mathrm{ml}^{-1}(480 \mathrm{ng} \mathrm{C} \mathrm{m})^{-1}\right)$; below $1.3 \times 10^{3} \mathrm{ml}^{-1}$ (62 $\mathrm{ng} \mathrm{C} \mathrm{ml^{-1 }}$ ), mortality occurred. Cell volume followed a rectangular hyperbolic response to food concentration, and showed a doubling in size between zero and maximum prey levels. Grazing rate initially increased with food concentration and was then inhibited at levels $>10^{4}$ prey $\mathrm{ml}^{-1}$. The ciliate ingested ${ }^{14} \mathrm{C}$-labelled live prey at higher rates than either dead or artificial prey at subsaturating concentrations; above saturating concentrations, ingestion rates were similar for the 3 prey types. The maximum observed grazing rate was 35 prey ciliate ${ }^{-1} h^{-1}$ Growth rate and cell volume were measured under steady-state conditions at 9 temperatures between 3.5 and $22^{\circ} \mathrm{C}$ : ciliates died at 3.5 and $5^{\circ} \mathrm{C}$, growth rate increased linearly to a maximum of $\mu \approx 0.9 \mathrm{~d}^{-1}$ at $15^{\circ} \mathrm{C}$, did not change between 15 and $20^{\circ} \mathrm{C}$, and decreased at $22^{\circ} \mathrm{C}$. Cell volume increased between 5 and $10^{\circ} \mathrm{C}$ and decreased between 10 and $22^{\circ} \mathrm{C}$. The population dynamics model revealed that the ciliate was able to control the dinoflagellate population. Over the $20 \mathrm{~d}$ model simulation, virtually no predator-prey cycle occurred when prey growth rates were $\mu<0.2 \mathrm{~d}^{-1}$ As prey growth rate was increased bloom dynamics became apparent, with a minimum duration of $-10 \mathrm{~d}$ for a bloom to begin and end at a prey growth rate of $\mu=0.65 \mathrm{~d}^{-1}$. During these simulated blooms ciliates reached maximum levels of $35 \mathrm{cells} \mathrm{ml}^{-1}$, and prey reached levels of $1.7 \times 10^{4}$ cells $\mathrm{ml}^{-1}$, similar to numbers found in a typical coastal bloom. Our data and model suggest that ciliates and their prey produce episodic, short-term blooms, and we recommend that these events be evaluated more carefully in the field and be incorporated into models.
\end{abstract}

KEY WORDS: Blooms - Cell volume Grazing rate 'Growth rate - Microzooplankton - Mortality rate Oligotrich ciliate - Plankton Temperature response

\section{INTRODUCTION}

The oligotrich ciliate Strombidinopsis is cosmopoli$\tan$ and is a conspicuous member of the microzooplankton (Lynn et al. 1991). This oligotrich is also relatively easy to culture (Montagnes 1993, Montagnes

\footnotetext{
·E-mail: dmontag@liv.ac.uk
}

et al. 1996), making it a tractable model-organism for assessing oligotrichs.

Typically, 1 to 10 oligotrichs $\mathrm{ml}^{-1}$ occur in marine waters (Lynn \& Montagnes 1991) but mechanisms controlling their abundances are poorly understood. Copepod predation may maintain a relatively constant ciliate abundance (Nielsen \& Kiørboe 1994), but populations of oligotrichs and their prey can fluctuate 


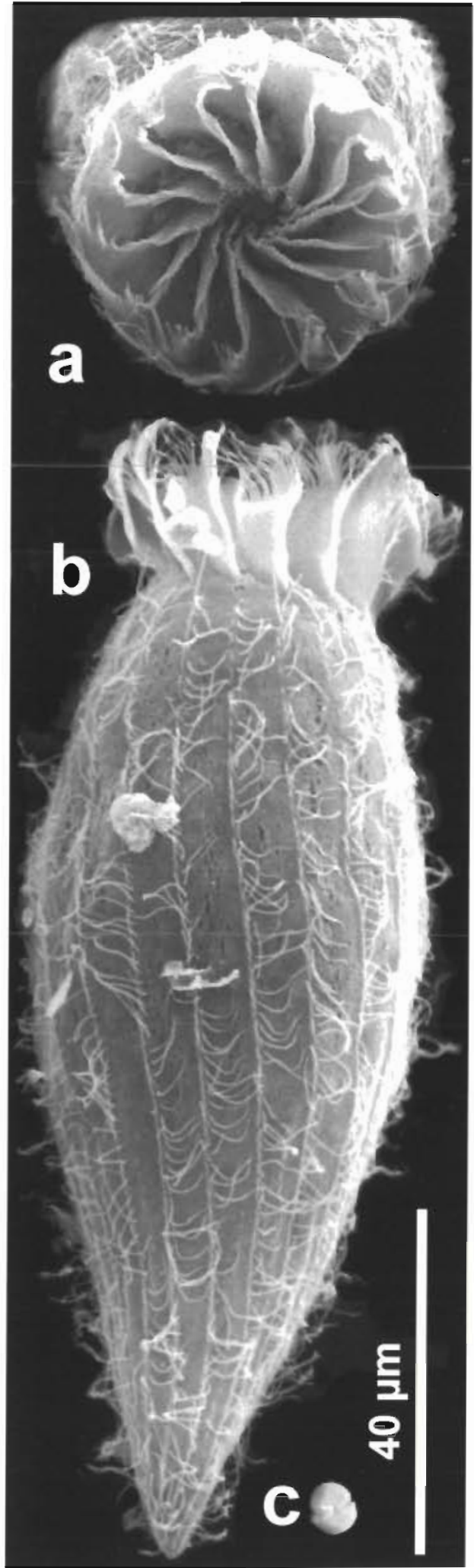

Fig. 1 Scanning electron micrographs of Strombidinopsis multiauris (a) oral view and (b) lateral view, and (c) Gymno. dinium simplex greatly, forming short-term blooms (e.g. Andersen \& Sørensen 1986). It may be that isolated ciliate populations regularly exploit prey patches in the plankton (e.g. Tiselius et al. 1993), which can result in local accumulations of ciliates (e.g. Nielsen et al. 1993, Montagnes et al. 1999).

Therefore, although ciliate assemblages may appear to remain constant over large temporal and spatial scales, there may be a succession of population blooms governed largely by bottom-up control (Nielsen \& Kiorboe 1994). If conditions become unstable (e.g. zooplankton predation is reduced or prey bloom), oligotrichs may bloom for periods ranging from hours to days (e.g. Smetacek 1981, 1984, Andersen \& Sørensen 1986, Dale \& Dahl 1987, Montagnes et al. 1988, Rassoulzadegan ct al. 1988).

To assess the potential for ciliates to exploit transient prey blooms, reliable estimates of growth and grazing rates are needed. In this study we present growth and grazing rates of Strombidinopsis multiauris, a planktonic oligotrich. We also present data on the temperature dependence of growth rate and cell volume of $S$. multiauris. We then use our data in a simple model (Montagnes 1993) to investigate ciliate-prey (i.e. S. multiauris-Gymnodinium simplex) population dynamics, asking the questions: (1) Can ciliates control prey populations? (2) What is the duration of predatorprey cycles? (3) What are the magnitudes of predator and prey abundance in these cycles?

\section{METHODS AND MATERIALS}

Isolation and general culturing. A clone of Strombidinopsis multiauris Montagnes \& Taylor, 1995 (Fig. 1) was isolated in May 1994 from Puget Sound (WA, USA) coastal waters (depth $0.5 \mathrm{~m}$, salinity $28 \%$, temperature $\sim 10^{\circ} \mathrm{C}$ ). By June 1995 the clone had died, likely due to clonal ageing (see Montagnes et al. 1996). While the clone was healthy (i.e. maximum growth rate was constant), experiments were performed on the ciliate.

Strombidinopsis multiauris did not grow when fed the flagellates Isochrysis galbana and Rhodomonas lens and grew for $<10 \mathrm{~d}$ when fed the flagellate Chroomonas salina and the diatom Thalassiosira pseudonana. However, the ciliate grew well when fed the dinoflagellate Gymnodinium simplex (Fig. 1, $\sim 8 \times$ $10 \mu \mathrm{m}, 48 \mathrm{pg} \mathrm{C}$ cell $^{-1}$; Menden-Deuer \& Lessard unpubl. data). All the following experiments used G. simplex as food.

Growth. Numerical response: The numerical response was determined for Strombidinopsis multiauris grazing on Gymnodinium simplex. The dinoflagellate was grown in f/2 medium (Guillard 1975) and maintained in $250 \mathrm{ml}$ polycarbonate flasks at $13^{\circ} \mathrm{C}$ on a 
14:10 h light:dark cycle at an irradiance of $-50 \mu \mathrm{mol}$ photons $\mathrm{m}^{-2} \mathrm{~s}^{-1}$. Prior to the experiments, S. multiauris was maintained with $G$. simplex in $\mathrm{f} / 200 \mathrm{tm}+\mathrm{vit}$ (Lessard 1993) in 6-well $20 \mathrm{ml}$ tissue culture plates at $13^{\circ} \mathrm{C}$ on a 14:10 h light:dark cycle at $\sim 10 \mu \mathrm{mol}$ photons $\mathrm{m}^{-2} \mathrm{~s}^{-1}$ For experiments, ciliates were collected during exponential phase from cultures containing prey ranging from $10^{3}$ to $10^{4}$ prey $\mathrm{ml}^{-1}$.

During the experiments, ciliates were grown in the dark (to prevent prey growth and the potential for mixotrophy) in 6-well, $20 \mathrm{ml}$ plastic tissue culture plates containing $8 \mathrm{ml}$ of prey and medium. This method works well for estimating ciliate growth, i.e. there was no significant difference between growth rate when ciliates were grown in tissue plate wells and $500 \mathrm{ml}$ containers which were mixed once per day (but ciliates died in containers that were rotated at $1 \mathrm{rpm}$, data not shown). There was no attempt to remove background bacteria $\left(-10^{6} \mathrm{ml}^{-1}\right)$; these had no significant affect on the growth rate of Strombidinopsis multiauris (data not shown).

The growth rate of Strombidinopsis multiauris was determined at prey concentrations ranging from 0 to $5 \times 10^{4}$ prey $\mathrm{ml}^{-1}$. Prey concentrations, assessed by a Coulter Counter, were made by diluting stock cultures with $\mathrm{f} / 200$ tm +vit.

For each prey concentration, 10 ciliates were placed in each of 3 wells in a tissue culture plate, using a finely drawn Pasteur pipette; this procedure has no significant affect on ciliate growth (data not shown). The cultures were then acclimated in the dark for $48 \mathrm{~h}$ at $13^{\circ} \mathrm{C}$. After the acclimation period, the prey concentrations were remade and allocated to 3 new wells. Then, 10 randomly chosen ciliates were removed from each of the acclimated wells and transferred to the new wells. The acclimated ciliates were incubated for a second 48 h period, at the end of which all cells in a well were counted; growth rate was estimated over the second $48 \mathrm{~h}$ period. The prey concentration used in the numerical response was the geometric mean concentration of each well during the second $48 \mathrm{~h}$ incubation (on average prey declined by $10 \%$ ). Growth rate $\left(\mu, \mathrm{d}^{-1}\right)$ was calculated over the second $48 \mathrm{~h}$ period as $\mu=\ln \left(\right.$ cells $_{t+1} /$ cells $\left._{t}\right) / t$, where $t=$ time in days (i.e. exponential growth was assumed over $48 \mathrm{~h}$ ).

The numerical response data were fit to a modified Michaelis-Menten model, with a non-zero $x$-intercept (Eq. 1). This model is a good predictor of numerical responses and is based on theoretically sound mechanisms (Fenchel 1986).

$$
\mu=\left\{\mu_{\max } \cdot\left([\mathrm{P}]-x^{\prime}\right)\right\} /\left\{k+\left([\mathrm{P}]-x^{\prime}\right)\right\}
$$

where $\mu=$ growth rate $\left(\mathrm{d}^{-1}\right) ; \mu_{\max }=$ the maximum growth rate $\left(\mathrm{d}^{-1}\right) ;[\mathrm{P}]=$ prey concentration $\left(\mathrm{no} . \mathrm{ml}^{-1}\right)$; $x^{\prime}=$ the $x$-intercept or threshold concentration (the prey concentration where $\mu=0$ ) (no. $\mathrm{ml}^{-1}$ ); and $k=\mathrm{a}$ constant (no. $\mathrm{ml}^{-1}$ )

Curves were fit to the data using the Marquardt-Levenberg algorithm (Sigmaplot, SPPS Inc., IL, USA). For biological data sets, this method may be more accurate and precise than methods of curve fitting that transform the model to linear forms (Berges et al. 1994).

Cell volume: Protozoan cell volume can change with food concentration. Thus, comparing growth rates as described above at different food concentrations may not represent biomass production at different food concentrations. Cell volume of Strombidinopsis multiauris was measured at 9 prey concentrations. After incubation, ciliates were preserved with $5 \%$ acid Lugol's iodine, and $\sim 50$ cells were measured using an inverted microscope equipped with a computer-aided digitising system. For volume estimation, ciliate shape was approximated as a cone topped by a section of a cone (i.e. a cylinder with one end smaller than the other). Cells shrank due to fixation; although we have not corrected for shrinkage, live volume may be determined assuming a $65 \%$ shrinkage factor (Jerome et al. 1993). However, the influence of food concentration on shrinkage has not been determined.

Cell volume versus food concentration was fit to a modified Michaelis-Menten model, with a non-zero $y$-intercept (Eq. 2).

$$
V=\left\{\left(V_{\max } \cdot[\mathrm{P}]\right) /(k+[\mathrm{P}])\right\}+b
$$

where $V=$ cell volume $\left(\mu \mathrm{m}^{3}\right) ; V_{\max }=$ maximum volume $\left(\mu \mathrm{m}^{3}\right)$; and $b\left(\mu \mathrm{m}^{3}\right)=$ non-zero intercept (i.e. the predicted size of cells at zero food)

Grazing. Functional response: Three methods were used to determine the effect of prey concentration on the grazing rate of Strombidinopsis multiauris: uptake of fluorescently labelled latex beads; uptake of heatkilled, fluorescently labelled Gymnodinium simplex (FLA); and uptake of ${ }^{14} \mathrm{C}$-labelled $G$. simplex.

Beads: Fluorescently labelled, $5 \mu \mathrm{m}$ latex beads (Seradyn, Particle Tech. Div., Indianapolis, IN, USA) were used to simulate Gymnodinium simplex. The beads, which were suspended in a toxic surfactant, were rinsed with distilled water (by serial centrifugation) and resuspended in a $5 \%$ bovine serum albumen-distilled water solution for $>10 \mathrm{~d}$, to reduce clumping (Pace \& Bailiff 1987); this solution was stored at $4^{\circ} \mathrm{C}$. Prior to use the beads were rinsed with prefiltered seawater and resuspended by sonication.

FLA: Gymnodinium simplex was heat-killed and stained to produce FLAs (Sherr \& Sherr 1993).

${ }^{14}$ C-Labelled Gymnodinium simplex: Gymnodinium simplex was grown in $\mathrm{f} / 2$ medium with ${ }^{14} \mathrm{C}$ bicarbonate $\left(\mathrm{NaH}^{14} \mathrm{CO}_{3}, 1 \mu \mathrm{C} \mathrm{ml}{ }^{-1}\right)$ until cells were uniformly labelled $(6 \mathrm{~d}, \sim 4$ generations; Welschmeyer \& Lorenzen 1984). Just prior to the grazing experiment, 
unincorporated ${ }^{14} \mathrm{C}$ was removed by rinsing the cells with filtered seawater over a $2 \mu \mathrm{m}$ polycarbonate filter and resuspending the cells in filtered seawater. Specific activity (disintegrations $\mathrm{min}^{-1}$ [DPM] cell-1) was determined as follows: aliquots of the washed, labelled stock culture were placed in $7 \mathrm{ml}$ liquid scintillation (LSC) vials, to which $0.2 \mathrm{~N}$ perchloric acid was added to digest cells and remove inorganic carbon. Liquid scintillation fluor (Biofluor, Packard) was added and radioactivity was measured with a Packard 2250CA LSC. To determine cell concentration, aliquots of prey were preserved in $0.5 \%$ glutaraldehyde, filtered onto $0.8 \mu \mathrm{m}$ black polycarbonate filters, and counted with an epifluorescent microscope using blue light excitation.

Grazing experiments: For all 3 experiments, 11 liveprey concentrations were made by diluting a culture of Gymnodinium simplex with $\mathrm{f} / 200 \mathrm{tm}+\mathrm{vit}$. Initially, ciliates were harvested in exponential phase from preyreplete cultures $\left(>3 \times 10^{4}\right.$ prey $\left.\mathrm{ml}^{-1}\right)$ and introduced to tissue culture plate wells containing the experimental prey concentrations. These ciliates were then acclimated at $13^{\circ} \mathrm{C}$ in the dark at each prey concentration for $48 \mathrm{~h}$ prior to incubations.

The grazing incubations were run at particle concentrations ranging from 500 to $4.5 \times 10^{4}$ prey $\mathrm{ml}^{-1}$ (beads or labelled Gymnodinium simplex plus unlabelled G. simplex in a 1:1 ratio). On the day of the grazing experiment, after the $48 \mathrm{~h}$ acclimation period, new prey concentrations (identical to those used for the acclimation period) were made. Four ml of each prey treatment was placed in tissue plate wells; each treatment was replicated 3 times. Acclimated ciliates $(\sim 80)$ were then transferred, using finely drawn pipettes, to the wells containing the $4 \mathrm{ml}$ of prey and acclimated for a further $2 \mathrm{~h}$ at $13^{\circ} \mathrm{C}$ at $10 \mu \mathrm{mol}$ photons $\mathrm{m}^{-2} \mathrm{~s}^{-1}$.

During the $2 \mathrm{~h}$ acclimation period concentrations of beads or labelled-prey treatments that equalled the unlabelled-prey treatments were prepared and counted on a Coulter Counter (or for ${ }^{14} \mathrm{C}$-labelled prey, by epifluorescent microscopy). After the $2 \mathrm{~h}$ acclimation period, $4 \mathrm{ml}$ of bead or labelled-prey treatment was added to the appropriate well treatment, thus exposing the ciliates to $8 \mathrm{ml}$ of 1:1 labelled prey:unlabelled prey at the 11 concentrations. The mixtures were incubated at $13^{\circ} \mathrm{C}$ and $10 \mu \mathrm{mol}$ photons $\mathrm{m}^{-2} \mathrm{~s}^{-1}$ for $30 \mathrm{~min}$ (grazing rate was constant for $>40 \mathrm{~min}$ after prey were added)

For the beads and FLA treatments, after the $30 \mathrm{~min}$ incubation, the $8 \mathrm{ml}$ in each well was transferred to a vial, fixed with acid Lugol's iodine (final concentration $5 \%$ ) and later bleached with concentrated sodium thiosulphite (as Lugol's masks fluorescence). Typically 50 ciliates were examined using $10 \mathrm{ml}$ settling chambers and an inverted epifluorescence microscope (blue excitation). The mean number of beads or FLA ciliate-1 was determined and the ingestion rate was estimated; ingestion rate was approximately twice the number of beads in the ciliates (depending on the actual ratio of beads/FLA:live prey at each treatment level).

For the ${ }^{14} \mathrm{C}$ treatments, after the 30 min incubation, the $8 \mathrm{ml}$ in each well was observed under a darkfield dissection microscope. All the ciliates were removed and placed in sterile filtered $\mathrm{f} / 200 \mathrm{tm}+\mathrm{vit}$ in $1 \mathrm{ml} \mathrm{de}$ pression wells at $-5^{\circ} \mathrm{C}$. The ciliates were subsequently transferred through 3 washes of $\mathrm{f} / 200 \mathrm{tm}+\mathrm{vit}$ to remove all uningested prey. Then, for each replicate, 10 ciliates were placed in each of 5 scintillation vials (i.e. 50 ciliates were examined per replicatej. Blank vials were prepared with $0.1 \mathrm{ml}$ unlabelled medium. To digest cells and drive off inorganir carbon. $0.2 \mathrm{ml}$ of $0.2 \mathrm{~N}$ perchloric acid was added to the vials. After $1 \mathrm{~h}$, $4 \mathrm{ml}$ of liquid scintillation fluor (Biofluor) was added to each vial, and radioactivity was determined. Radioactivity in samples of cell-free final wash water was below background levels. The mean number of labelled prey ciliate ${ }^{-1}$ was determined by dividing the total background-corrected radioactivity (DPM) in a vial by the specific activity of Gymnodinium simplex (DPM $\mathrm{cell}^{-1}$ ) and the total number of ciliates in the vial. Ingestion rate was approximately twice the number of labelled prey per ciliate (depending on the actual ratio of labelled prey:unlabelled prey at each treatment level).

Analysis of functional response: Using the Marquardt-Levenberg algorithm, grazing rates were fit to Eq. (3), which models a response similar to Eq. (1) but includes an inhibition term (Spain 1982).

$$
G=G_{\max } /(1+k /[\mathrm{P}]+[\mathrm{P}] / i)
$$

where, $G=$ grazing rate (prey ciliate ${ }^{-1} \mathrm{~h}^{-1}$ ); $G_{\max }$ (prey ciliate $^{-1} \mathrm{~h}^{-1}$ ), and $i$ and $k$ (no. prey $\mathrm{ml}^{-1}$ ) are predicted parameters.

Differences between the responses of the 3 treatments were analysed by dividing the 3 data sets into 2 components: (1) the initial increase in grazing rate, when prey concentration was limiting and (2) the grazing rates when prey levels were saturating. These 2 distinct response regions were analysed separately by linear regression methods (Zar 1984); see 'Results' for details

Gross growth efficiency. The gross growth efficiency (GGE) over the range of prey concentrations was calculated as:

$$
\mathrm{GGE}=\mu \quad V_{c} \cdot 0.19 / G \cdot 48
$$

where $\mu=$ intrinsic rate of increase (Eq. 1$)_{i} V_{c}=$ ciliate cell volume (Eq. 2); $0.19=\mathrm{pg}$ of carbon $\mu \mathrm{m}^{-3}$ of ciliate (Putt \& Stoecker 1989); $G=$ prey grazed $d^{-1}$ (Eq. 3 $\times 24 \mathrm{~h}$ ); and $48=$ pg carbon prey ${ }^{-1}$ (Menden-Deuer \& Lessard unpubl.). 
Temperature. To determine the effect of temperature on growth rate, ciliates were grown at a saturating food concentration at 9 temperatures. This experiment followed a protocol similar to that described above 'Numerical response', but temperature, not food concentration, was varied. Ciliates were maintained at $3.5 \times 10^{4}$ prey $\mathrm{ml}^{-1}$ at $3.5,5.0,8.5,10.0,11.5,13.5,15.0$, 19.0 , and $22.0^{\circ} \mathrm{C}$, in $10 \mathrm{ml}$ of medium, in tissue culture plate wells. Six replicate wells, initially containing 10 ciliates, were acclimated at these temperatures for $48 \mathrm{~h}$. After the acclimation period new food concentrations were made, brought to the appropriate temperatures, and 10 ciliates from each acclimated replicate were transferred to a new well. The wells were then incubated for $48 \mathrm{~h}$, the number of cells per well determined, and exponential growth rate $\left(\mu, \mathrm{d}^{-1}\right)$ calculated over $48 \mathrm{~h}$. After enumeration, all cells were preserved with $5 \%$ acid Lugol's iodine and their volumes measured as described above.

Bloom model. We investigated short-term, smallscale population dynamics of Strombidinopsis multiauris and Gymnodinium simplex using a coupled predatorprey model that is numerically solved using difference equations coded in BASIC and evaluated in computer simulations, with time steps of $0.05 \mathrm{~d}$ (modified from a model presented by Montagnes 1993). The questions we investigated were: Can the ciliate control prey populations? What is the duration of predator-prey cycles? What are the magnitudes of predator and prey abundances in these cycles?

The following assumptions were made for a $20 \mathrm{~d}$ simulation: advection of organisms in or out of the localised system is negligible; conditions (e.g. nutrients and light) influencing phytoplankton growth rate did not change (i.e. growth rate was constant); and mesozooplankton abundance was low $\left(0.1 \mathrm{I}^{-1}\right)$. These are conditions where ciliate blooms might occur and where ciliates could have a selective advantage over mesozooplankton, (Montagnes 1993).

The model simulated the population dynamics of Gymnodinium simplex and Strombidinopsis multiauris during transient conditions, where the ciliates encounter a region of water with a defined initial prey concentration. A copepod predator was included in the model at a constant level of $0.1 \mathrm{l}^{-1}$. The copepod grazed both ciliates and dinoflagellates, based on size-specific grazing rates established from data presented in Frost (1972) on Calanus pacificus grazing on diatoms. Each run of the model began with $10^{3}$ prey $\mathrm{ml}^{-1}$ and 1 ciliate $\mathrm{ml}^{-1}$; these levels represent average concentrations in many coastal waters (Montagnes 1993). During each simulation the prey grew exponentially at a constant, defined rate (this was varied between $\mu=0.15$ and $0.65 \mathrm{~d}^{-1}$ ). Prey mortality was a function of ciliate predation (Eq. 3, using parameters obtained from ${ }^{14} \mathrm{C}$ exper-
Table 1. Growth, volume and grazing data for Strombidinopsis multiauris. Parameters and estimates of error of the numerical response equation (Eq. 1) presented in Fig. 2; volume response (Eq. 2) presented in Fig. 3; and functional response (Eq. 3) presented in Fig. 4. Parameters, standard errors, and coefficients of variation were calculated using a curve fitting package (SPSS Inc., IL)

\begin{tabular}{|c|c|c|c|}
\hline Parameter (units) & Value & $\mathrm{SE}$ & $\mathrm{CV}(\%)$ \\
\hline \multicolumn{4}{|c|}{ Modified Michaelis-Menten fit from Fig. 1} \\
\hline$\mu_{\max }\left(\mathrm{d}^{-1}\right)$ & 0.622 & 0.038 & 6.0 \\
\hline$k\left(\right.$ no. $\left.\mathrm{ml}^{-1}\right)$ & 2384 & 293 & 12 \\
\hline$x^{\prime}\left(\right.$ no. $\left.\mathrm{ml}^{-1}\right)$ & 1308 & 124 & 9.4 \\
\hline \multicolumn{4}{|c|}{ Modified Michaelis-Menten fit from Fig. 2} \\
\hline$V_{\max }\left(\mu \mathrm{m}^{3}\right)$ & $1.43 \times 10^{5}$ & $2.3 \times 10^{4}$ & 16 \\
\hline$k\left(\mathrm{no} \cdot \mathrm{ml}^{-1}\right)$ & $2.34 \times 10^{4}$ & 9425 & 40 \\
\hline$b\left(\mu \mathrm{m}^{3}\right)$ & $7.70 \times 10^{4}$ & 4770 & 6.2 \\
\hline \multicolumn{4}{|c|}{ Grazing with inhibition fit from Fig. 3 , line (beads) } \\
\hline$G_{\max }\left(\right.$ prey $\left.\mathrm{h}^{-1}\right)$ & 3613 & $1.13 \times 10^{5}$ & 3143 \\
\hline$k\left(\right.$ no. $\left.\mathrm{ml}^{-1}\right)$ & $1.2 \times 10^{6}$ & $3.8 \times 10^{7}$ & 3156 \\
\hline$i\left(\right.$ no. $\left.\mathrm{ml}^{-1}\right)$ & 246 & 7946 & 3229 \\
\hline \multicolumn{4}{|c|}{ Grazing with inhibition fit from Fig. 3 , long dashes (FLA) } \\
\hline$G_{\max }\left(\right.$ prey $\left.^{-1}\right)$ & 2902 & $2.02 \times 10^{6}$ & 3517 \\
\hline$k\left(\right.$ no. $\left.\mathrm{ml}^{-1}\right)$ & $8.48 \times 10^{5}$ & $3 \times 10^{7}$ & 3536 \\
\hline$i\left(\right.$ no. $\left.\mathrm{ml}^{-1}\right)$ & 286 & 9552 & 3341 \\
\hline \multicolumn{4}{|c|}{ Grazing with inhibition fit from Fig. 3 , short dashes $\left({ }^{14} \mathrm{C}\right)$} \\
\hline$G_{\max }\left(p^{\prime} \mathrm{h}^{-1}\right)$ & 197 & 211 & 107 \\
\hline$k\left(\right.$ no. $\left.\mathrm{ml}^{-1}\right)$ & $1.9 \times 10^{4}$ & $2.4 \times 10^{4}$ & 125 \\
\hline$i\left(\right.$ no. $\left.\mathrm{ml}^{-1}\right)$ & 3314 & 4096 & 124 \\
\hline
\end{tabular}

iments, Table 1) and copepod predation on dinoflagellates (Eq. 5).

$$
G=\left(G_{\max } \cdot[\mathrm{P}]\right) /(k+[\mathrm{P}])
$$

where $G=$ copepod grazing rate on the prey (prey $\mathrm{h}^{-1}$ copepod $^{-1}$ ); $G_{\max }=$ the maximum grazing rate (dinoflagellate $h^{-1}$ copepod $\left.^{-1}\right)=11750 ;[P]=$ prey concentration (no. $\mathrm{ml}^{-1}$ ); and $k=$ the half saturation constant (no. $\left.\mathrm{ml}^{-1}\right)=1900$. Change in ciliate numbers was determined by growth and mortality as a function of prey concentration (Eq. 1, using parameters obtained from growth experiments, Table 1) and copepod predation on ciliates (Eq. 5), where $G_{\max }=600$ and $k=45$.

\section{RESULTS}

\section{Growth}

\section{Numerical response}

Ciliate growth rate followed a rectangular hyperbolic response from 0 to $5 \times 10^{4} \mathrm{prey} \mathrm{m}^{-1}$ (Fig. 2). Maximum growth rate of $\sim 0.6$ occurred above $2 \times 10^{4}$ prey $\mathrm{ml}^{-1}$. Below $1.3 \times 10^{3}$ prey $\mathrm{ml}^{-1}$, ciliate intrinsic mor- 


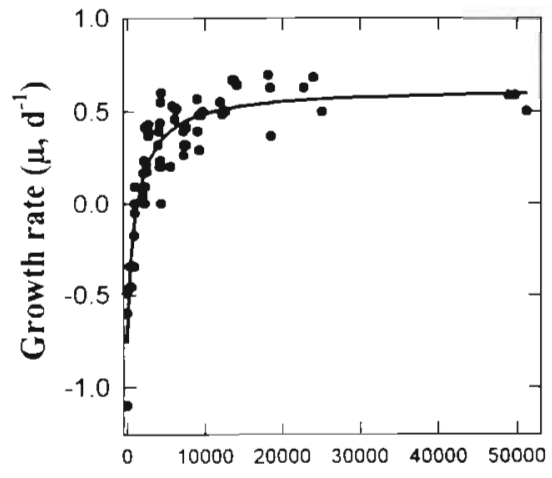

Prey concentration (No. $\mathrm{ml}^{-1}$ )

Fig. 2. Numerical response of Strombidinopsis multiauris. All data points represent growth rates. The curve is the modified Michaelis-Menten fit (Eq. 1) to the data (see Table 1 for the parameters associated with this curve)

tality (henceforth referred to as mortality) occurred. Eq. (1) was fit to the data (Fig. 2, Table 1).

\section{Cell volume}

Ciliate cell volume versus food concentration followed a rectangular hyperbolic response, with a predicted minimum volume of $7.7 \times 10^{4} \mu \mathrm{m}^{3}$ (when no food was present and cells had been starved for $48 \mathrm{~h}$ ). Note that this value, and other estimates of subthreshold cell volumes, are transitional states. A maximum observed volume of $1.7 \times 10^{5} \mu \mathrm{m}^{3}$ occurred near $4.5 \times 10^{4}$ prey $\mathrm{ml}^{-1}$. Eq. (2) was fit to the data (Fig. 3, Table 1).

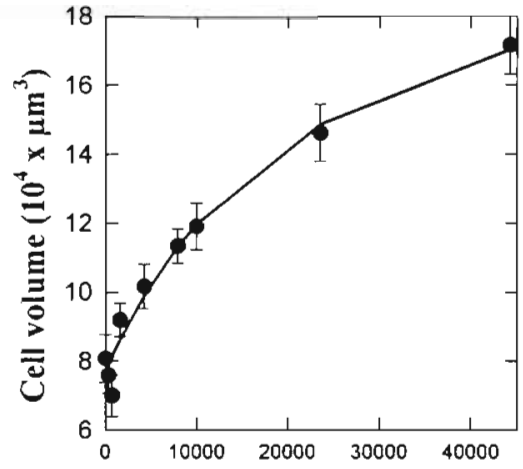

Prey concentration (No. $\mathrm{ml}^{-1}$ )

Fig. 3. Relation between cell volume of Strombidinopsis multiauris and food concentration. Data points represent mean voiume uf $\sim 50$ celis. Erior bais represent 1 standard error. The curve is the modified Michaelis-Menten fit (Eq. 2) to the data (see Table 1 for the parameters associated with this curve)

cantly different from each other (ANCOVA $F_{2,69}=34$, followed by Tukey multiple range test, $\alpha=0.05$ for all tests). Between 2 and $4.5 \times 10^{4} \mathrm{prey} \mathrm{ml}^{-1}$, there was no difference between slopes or elevations of the 3 treatments (ANCOVA, $F_{2,21}=0.53, F_{2,22}=2.43$, respectively, $\alpha=0.05)$; over this range grazing rate decreased with food concentration, indicating an inhibition with food concentration $\left(F_{1,25}=21, \alpha=0.05\right)$.

\section{Gross growth efficiency}

Gross growth efficiency (GGE) rapidly increased from 0 to -0.2 , between 1.3 and $3 \times 10^{3}$ cells ml ${ }^{-1}$; it slowly increased from $\sim 0.2$ to a maximum of $\sim 1.2$

\section{Grazing}

For all 3 methods (beads, FLA, ${ }^{14} \mathrm{C}$ ), grazing rate of Strombidinopsis multiauris on Gymnodinium simplex increased between 0 and $10^{4}$ prey $\mathrm{ml}^{-1}$. Above $10^{4}$ prey $\mathrm{ml}^{-1} \mathrm{graz}$ ing rate decreased, i.e. grazing did not follow a rectangular hyperbolic function. Eq. (3) was fit to the 3 data sets (Fig. 4, Table 1).

Least squares linear regression analysis was performed on segments of the grazing data to assess differences between techniques. Between 0 and $10^{4}$ prey $\mathrm{ml}^{-1}$ regressions of grazing rate versus prey concentration were forced through the origin. Over this range, the slope of the ${ }^{14} \mathrm{C}$ grazing rate versus food concentration was significantly higher than that determined by either beads or FLAs; the latter 2 slopes were not signifi-

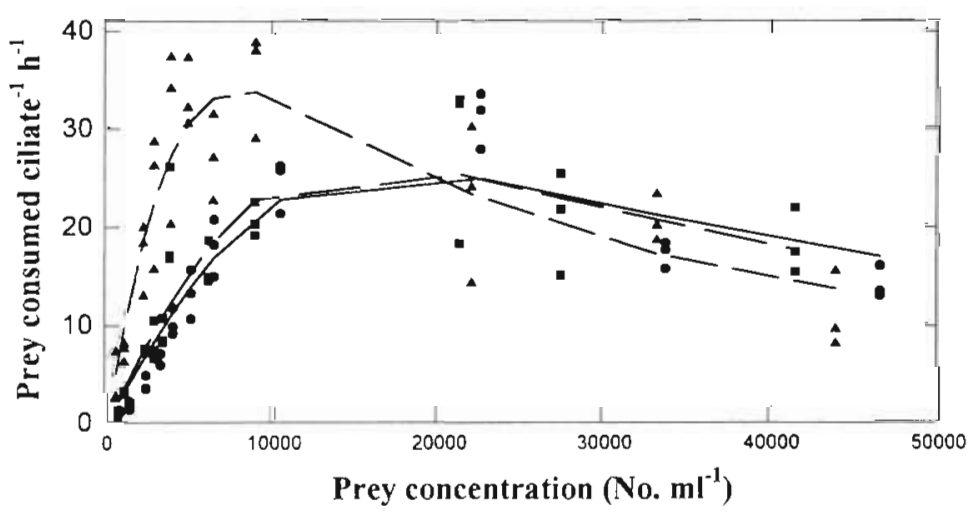

Fig. 4. Functional response of Strombidinopsis multiauris using 3 different methods: uptake of fluorescently labelled, $5 \mu \mathrm{m}$, latex beads (solid line, circles); uptake of heat-killed, fluorescently labelled Gymnodinium simplex (FLA) (long-dashed line, squares); and uptake of ${ }^{14} \mathrm{C}$-labelled G. simplex (small-dashed line, triangles). All data points represent grazing rates. The curves are the fit of Eq. (3) to the data (see Table 1 for the parameters associated with these curves) 


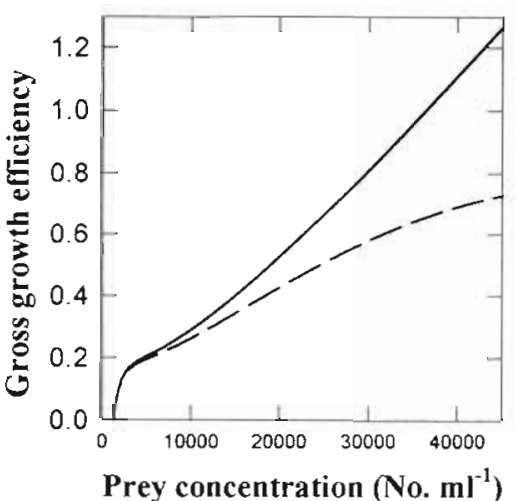

Fig. 5. Relationship between gross growth efficiency (GGE) and food concentration for Strombidinopsis multiauris (Eq. 4) (solid line); a modified estimate of GGE assuming a non-constant carbon to volume conversion (dashed line, see 'Discussion' for details)

between 3 and $4.5 \times 10^{4}$ cells $\mathrm{ml}^{-1}$ (solid line, Fig. 5). Values of GGE $>1$ are theoretically impossible and are considered in 'Discussion'.

\section{Temperature}

\section{Growth rate}

Ciliates grown at $3.5^{\circ} \mathrm{C}$ died within the $48 \mathrm{~h}$ acclimation period, and growth was only determined between 5.0 and $22.0^{\circ} \mathrm{C}$ (Fig. 6). Ciliates died at $5^{\circ} \mathrm{C} ; \mu=-0.14$. Between 8.5 and $15.0^{\circ} \mathrm{C}$, a linear growth rate could not be rejected, and this response increased from 0.14

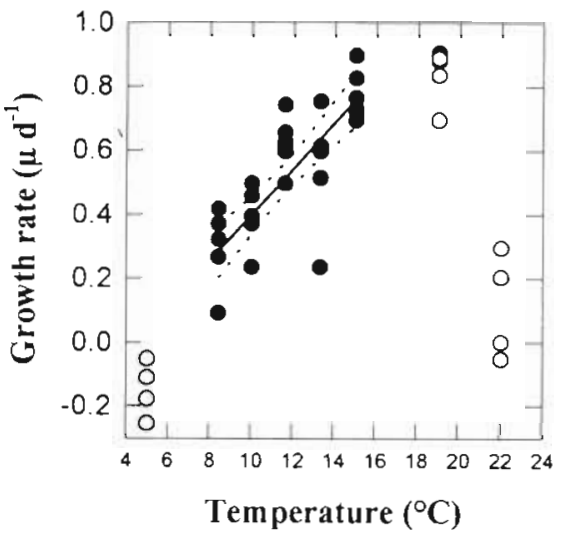

Fig. 6. Relationship between growth rate and temperature for Strombidinopsis multiauris. All data points represent growth rates. A linear regression (solid line) was fit through the solid data points (see text for details); open points were not considered as part of the linear response. The dotted lines are the $95 \%$ confidence intervals of the regression

to $0.77 \mathrm{~d}^{-1}$ (F-test, Zar 1984, $F_{3,24}=0.28, \alpha=0.05$, Table 2). The linear response of growth rate for this range can be predicted by the regression: $\mu=t \cdot 0.072$ $-0.321\left(r^{2}=0.64\right)$. Growth rate was constant between 15 and $19^{\circ} \mathrm{C}\left(\sim 0.85 \mathrm{~d}^{-1}\right)$ and decreased to $0.13 \mathrm{~d}^{-1}$ at $22^{\circ} \mathrm{C}$.

\section{Cell volume}

Ciliate volume increased with temperature between

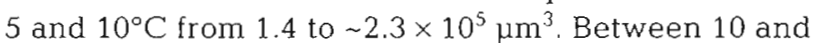
$22^{\circ} \mathrm{C}$ cell volume decreased from 2.3 to $1.2 \times 10^{5} \mu^{3}$ (Fig. 7).

Table 2. Slope of the linear response of growth rate $\left(\mu, \mathrm{d}^{-1}\right)$ versus temperature $\left({ }^{\circ} \mathrm{C}\right)$ for several planktonic and non-planktonic oligotrichous ciliates and other planktonic ciliates. Lines were fit to data where growth rate was positive and increased with temperature. The shape of the line was assessed by using a non-linear curve fitting program (Sigmaplot, SPSS Inc., IL) to fit data to the equation $\mu=a \cdot t^{b}+c$ (where $\mu$ is growth rate, $t$ is temperature and $a, b$, and $c$ are constants). The program provides a standard error for estimated parameters. The exror term associated with ' $b$ ' was used to test $(\alpha=0.05, t$-test) the null hypothesis $b=1$ (i.e. there was no exponential relationship). If the null hypothesis could not be rejected, the line was considered linear; if $b \neq 1$, it was considered exponential

\begin{tabular}{|c|c|c|c|c|c|c|}
\hline $\begin{array}{l}\text { Slope of } \\
\mu \text { vs } t\end{array}$ & Species & $\begin{array}{c}\text { Range } \\
\left({ }^{\circ} \mathrm{C}\right)\end{array}$ & $\begin{array}{l}\text { Line } \\
\text { shape }\end{array}$ & $\mathrm{n}$ & $\begin{array}{l}\text { Data } \\
\text { from }\end{array}$ & Source \\
\hline 0.072 & Strombidinopsis multiauris & $5-15$ & Linear & 36 & Fig. 6 & This study \\
\hline 0.108 & Urotricha farcta & $5-20$ & Linear & 12 & Table 1 & Weisse \& Montagnes (1998) \\
\hline 0.070 & Urotricha furcata \# (from L. Schohsee) & $5-20$ & Linear & 12 & Table 1 & Weisse \& Montagnes (1998) \\
\hline 0.075 & Urotricha furcata (from L. Constance) & $5-20$ & Linear & 12 & Table 1 & Weisse \& Montagnes (1998) \\
\hline 0.078 & Pseudobalanion planktonicum & $5.5-18.5$ & Linear & 6 & Table 2 & Müller \& Geller (1993) \\
\hline 0.079 & Urotricha furcata & $5.5-21.5$ & Exponential & 6 & Table 2 & Müller \& Geller (1993) \\
\hline 0.056 & Pelagostrombidium fallax & $5.5-21.5$ & Linear & 6 & Table 2 & Müller \& Geller (1993) \\
\hline 0.069 & Strobilidium lacustris & $5.5-21.5$ & Linear & 5 & Table 2 & Müller \& Geller (1993) \\
\hline 0.024 & Favella sp. & $8-21$ & Linear & 5 & Fig. 3c & Aelion \& Chisholm (1985) \\
\hline 0.072 & Tintinnopsis acuminata & $15-25$ & Linear & 3 & Table 3 & Verity (1985) \\
\hline 0.072 & Strombidium sulcatum & $15-30$ & Linear & 5 & Figs. 1-5 & Martinez (1983) \\
\hline 0.000 & Lohmanniella (=Strobilidium) spiralis & $15-24$ & Linear & 4 & Fig. 2 & Rassoulzadegan (1982) \\
\hline 0.096 & Fabrea salina & $22-29$ & Linear & 4 & Fig. 5 & Winter \& Persoone (1975) \\
\hline
\end{tabular}




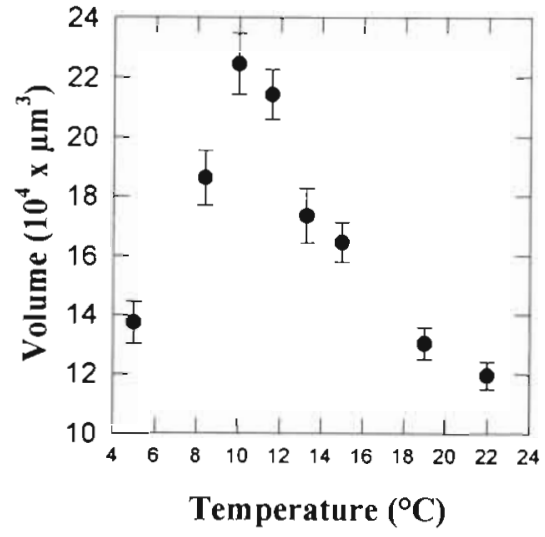

Fig. 7. Relationship between cell volume and temperature for Strombidinopsis multiauris. Data points are mean volumes of $\sim 50$ cells. Error bars are 1 standard error

\section{Bloom model}

Under most conditions examined, the ciliate was capable of controlling the dinoflagellate population (Fig. 8). Over the $20 \mathrm{~d}$ simulation, virtually no predatorprey cycle occurred when prey growth rates were $<0.2 \mathrm{~d}^{-1}$. As prey growth rate was increased $>0.2 \mathrm{~d}^{-1}$, bloom dynamics became apparent, with a minimum duration of $\sim 10 \mathrm{~d}$ for a ciliate bloom to begin and end at prey growth rates of $0.65 \mathrm{~d}^{-1}$. During these blooms, ciliates reached maximum levels of 35 cells $\mathrm{mll}^{-1}$ (Fig. 8a), and prey reached levels of $\sim 1.7 \times 10^{4}$ cells $\mathrm{ml}^{-1}$ (Fig. 8b).

Regardless of prey growth rate, in $1 \mathrm{ml}$, over the $20 \mathrm{~d}$ simulation, few ciliates $(<2)$ and few dinoflagellates (200 to 270) were eaten by copepods (Fig. 9). In contrast, the total number of dinoflagellates eaten by ciliates, in $1 \mathrm{ml}$, ranged from $2.5 \times 10^{3}$ to $5 \times 10^{4}$, as prey growth rate increased from 0.15 to $0.65 \mathrm{~d}^{-1}$ (Fig. 9).

\section{DISCUSSION}

\section{Implications of the numerical response}

The numerical response indicates that: (1) the threshold concentration (the prey level below which ciliates die) of Gymnodinium simplex for Strombidinopsis multiauris was $\sim 10^{3} \mathrm{ml}^{-1}$; (2) the major increase in growth rate occurred between $10^{3}$ and $10^{4}$ prey $\mathrm{ml}^{-1}$; and (3) the maximum growth rate was $\sim 0.6 \mathrm{~d}^{-1}$ (Fig. 2, Table 1). These data are consistent with those for other oligotrichs (Montagnes 1996), and specifically for Strombidinopsis, although only 4 other species of Strombidinopsis have been investigated (Fig. 10, Table 3). When these 4 species are compared, after scaling the growth responses to a common temperature of $16^{\circ} \mathrm{C}$ using a conversion of
$0.072 \mu^{\circ} \mathrm{C}^{-1}$ (see 'Temperature response' below), there are still inter-specific differences. These differences cannot be accounted for by ciliate size (Table 3), as might be predicted (Hansen et al. 1997). As prey type affects the growth rate of ciliates in general (Montagnes 1993) and Strombidinopsis specifically (Buskey \& Hyatt 1995, Jeong et al. 1999, this study), the differences observed between species may result from offering ciliates suboptimal food. The fact that ciliates respond to optimal prey suggests that planktonic ciliates may exploit patches of single preferred prey type when they become available; such a scenario is explored below ('Bloom dynamics').

Prey in the size range fed to Strombidinopsis multiauris tend to occur at levels of $-10^{3} \mathrm{ml}^{-1}$ but may be distributed into patches 2 - to 5 -fold higher and may form patches of 1 or 2 orders of magnitude higher than background levels. The numerical response of $S$. multiauris suggests that it would be just able to survive at background prey levels but would thrive at concentrations 5 to 10-fold higher. These data support the suggestion of Montagnes (1996) that many planktonic ciliates are adapted to exploit prey patches, and these patches must occur to allow the ciliate to exist, as mean food concentrations are often too low to support ciliate growth.
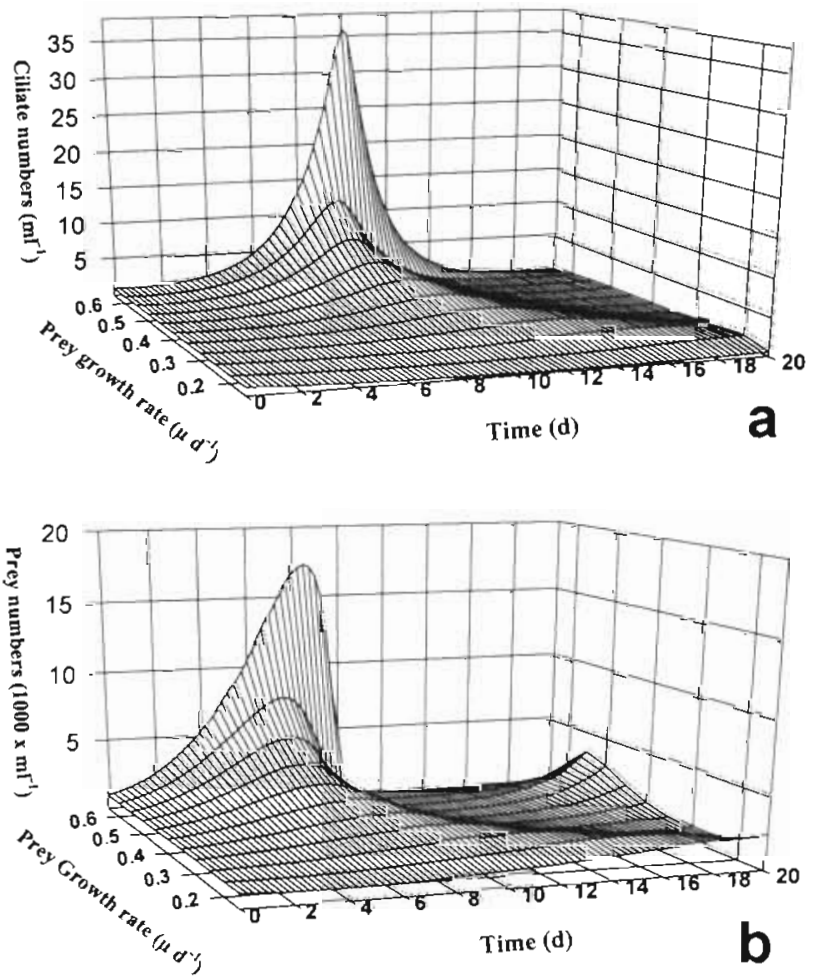

Fig. 8. (a) Ciliate and (b) dinoflagellate abundance during simulations of ciliate-prey dynamics over $20 \mathrm{~d}$, with varying prey growth rates. See 'Methods and materials' for a description of the model 


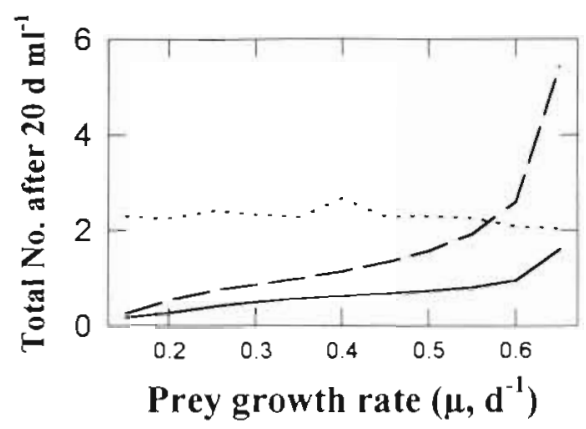

Fig. 9. Relationship between prey growth rate and total prey consumed by predators in $1 \mathrm{ml}$, over the $20 \mathrm{~d}$ simulation depicted in Fig. 8: dinoflagellates consumed by ciliates (dashed line $\times 10^{4}$ ); dinoflagellates consumed by copepods (solid line $\times 10^{2}$ ); ciliates consumed by copepods (dotted line)

\section{Volume changes}

Several aspects of ciliate energetics are dependent on cell size: ciliate production may be calculated by determining the product of growth rate and biomass, the latter being estimated from some average estimate of cell size; gross growth efficiency may be determined as the product of growth rate and cell volume divided by ingestion (e.g. Jakobsen \& Hansen 1997); and feeding encounter may be affected by prey size, due to changes in the area of encounter (Fenchel 1986).

Our data indicate that under semi-steady conditions, food concentration can alter the cell volume (and presumably the biomass) of Strombidinopsis multitauris by approximately 2 -fold, and this change follows a rectangular hyperbolic function (Fig. 3). Similar changes occur for both the ciliate Balanion comatum and the dinoflagellate Gymnodinium sp. (Jakobsen \& Hansen 1997). Volume changes in oligotrichs also occur under transient conditions: volume changes between late

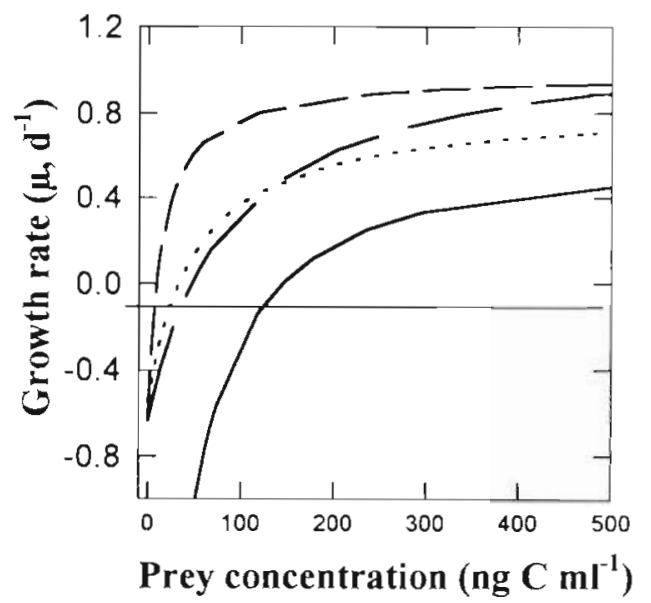

Fig. 10. Numerical response of 4 species of Strombidinopsis: Strombidinopsis sp. (solid line, data provided by E. Buskey, Marine Science Institute of Texas at Austin, Port Aransas) Strombidinopsis sp. (large-dashed line, Jeong et al. 1999); $S$. cheshiri (small dashed line, data obtained from Montagnes et al. 1996); S. multiauris (dotted line, data obtained from this study, Table 1). All responses were scaled to $16^{\circ} \mathrm{C}$ using a conversion of $0.072 \mu^{\circ} \mathrm{C}^{-1}$ (see 'Results: Temperature'). Prey concentrations when presented as numbers were converted to carbon using values form Montagnes et al. (1994) or values provided by the authors. The curves are the modified Michaelis-Menten fit (Eq. 1) to the data (see Table 3 for the parameters associated with these curves)

exponential and stationary cells of Strombidium sp. vary by almost 2 -fold (Ohman \& Snyder 1991), and well fed and starved cells of another Strombidium species vary by $\sim 8$-fold (Fenchel \& Jonsson 1988). Cell volume is therefore an important parameter to observe when examining ciliate bioenergetics.

Clearly, 2-fold changes in cell volume will affect production and GGE estimates (see 'Gross growth efficiency and assesment of growth and grazing esti-

Table 3. Parameters of the numerical responses (Eq. 1) for the Strombidinopsis species presented in Fig. 10. Raw data for Strombidinopsis sp. (solid line) were obtained from E. Buskey (Marine Science Institute of Texas at Austin, Port Aransas) but are also presented graphically in Buskey \& Hyatt (1995). Data for Strombidinopsis sp. (large-dashed line) were obtained from Jeong et al. (1999). Data for $S$. cheshiri (small-dashed line) were obtained from Montagnes et al. (1996). Data for S. multiauris (dotted line) were obtained from this study (Table 1). All responses were scaled to $16^{\circ} \mathrm{C}$ using a conversion of $0.072 \mu^{\circ} \mathrm{C}^{-1}$ (see 'Results: Temperature'); thus, parameters will differ from published values. Prey concentrations, when presented as numbers, were converted to carbon using values from Montagnes et al. (1994) or values provided by the authors

\begin{tabular}{|c|c|c|c|c|c|c|c|}
\hline Species & $\begin{array}{l}\mu_{\max } \\
\left(\mathrm{d}^{-1}\right)\end{array}$ & $\begin{array}{c}k \\
\left(\mathrm{ng} \mathrm{C} \mathrm{ml^{-1 }}\right)\end{array}$ & $\begin{array}{c}x^{\prime} \\
\left(\operatorname{ng} \mathrm{Cl}^{-1}\right)\end{array}$ & $\begin{array}{l}\text { Temp. } \\
\left({ }^{\circ} \mathrm{C}\right)\end{array}$ & $\begin{array}{l}\text { Line type } \\
\text { (Fig. 10) }\end{array}$ & $\begin{array}{l}\text { Live volume } \\
\qquad\left(\mu \mathrm{m}^{3}\right)\end{array}$ & Source \\
\hline Strombidinopsis sp. & 0.64 & 109.24 & 97.47 & 20 & Solid & 110433 & $\begin{array}{l}\text { E. Buskey } \\
\text { (pers. comm.) }\end{array}$ \\
\hline Strombidinopsis sp. & 1.01 & 111.19 & 25.76 & 19 & Large dash & 560000 & $\begin{array}{l}\text { Jeong et al. } \\
\text { (1999) }\end{array}$ \\
\hline S. cheshiri & 0.99 & 24.29 & 9.33 & 16 & Small dash & 92000 & $\begin{array}{l}\text { Montagnes } \\
\text { et al. (1996) }\end{array}$ \\
\hline S. multiauris & 0.85 & 114.20 & 62.88 & 13 & Dots & -186000 & This study \\
\hline
\end{tabular}


mates', below). Similarly, prey encounter, which depends more on cross-sectional area or linear dimensions, may also change. Although these changes would not be as great as that of volume, the effect would not be negligible and would be a productive direction for future study.

\section{Grazing}

Ciliates may discriminate against both surrogate and natural particles (Stoecker et al. 1986, Putt 1991, Landry 1994). Live, labelled prey appears both intuitively and empirically to be the best tracer of protozoan ingestion (e.g. Balczon \& Pratt 1995). Our data (Fig. 4) indicate that the slope of grazing rate versus food concentration is highest for ciliates fed ${ }^{14} \mathrm{C}$ labelled live prey, but there was no difference in the maximum grazing rates at saturating prey concentrations. These data indicate a preference for live prey when prey are limiting, but when prey levels are saturating ciliates are not selective.

Two important steps in the feeding process are prey capture and prey processing; prey capture limits feeding rate at low concentrations while processing time limits feeding rate at high concentrations (Fenchel 1986). If this is so, then our data suggest that, for the 3 prey types we investigated, processing time is invariant with food type, but that encounter rate is higher for the ${ }^{14} \mathrm{C}$-labelled prey. Three possible reasons for this are: swimming speed of live prey increases the encounter between ciliates and prey; ciliates are able to detect live-prey movement; or chemical cues from the live prey increase swimming/feeding behaviour (e.g. Buskey \& Stoecker 1989). These processes would increase the ciliate-prey affinity. A fourth possibility, which may have been occurring concurrently with the above explanations is that ${ }^{14} \mathrm{C}$-labelled prey may have been partially assimilated during the $0.5 \mathrm{~h}$ incubation, while beads and FLAs were not assimilated; this might lead to an apparent lower ingestion of FLAs or beads. We have used the ${ }^{14} \mathrm{C}$-labelled prey data to estimate the functional response of Strombidinopsis multiauris (Table 1) in the model discussed below.

Our data also indicate a strong effect of feeding inhibition at higher food concentrations. Feeding inhibition occurs in some planktonic oligotrichs but not in others (Heinbokel 1978, Verity 1985, Jonsson 1986, Montagnes 1996). The detection of inhibition may depend on the method of measurement of ingestion rates. Many studies have used long (24 to 48 h) incubations during which prey concentrations are significantly reduced (ingestion rate is indirectly measured from prey disappearance) and on average may not have been at inhibiting concentrations. We directly measured ingestion rate in short-term (30 min) experiments with low predator concentrations so that prey concentrations were little changed during incubation. As the ciliates had been pre-acclimated to the high food concentrations, inhibition was not likely a transient response to a change in food concentration (but see 'Gross growth efficiency and assesment of growth and grazing estimates', below).

The mechanism of the observed inhibition is unknown. Planktonic ciliates respond to both chemo- and mechanosensory stimuli (e.g. Buskey \& Stoecker 1989). A reduction in ciliate grazing could have resulted from an inhibitory chemical which reached a critical level at high prey concentrations. It is also possible that mechanical interference with feeding occurs at high food concentrations. The occurrence of, and mechanisms behind, the apparent inhibition of ingestion at high food concentrations deserves further study.

In our model (below), prey concentrations rarely reached levels where feeding inhibition would occur. Similarly, dinoflagellate concentrations of $>2 \times 10^{5}$ cells $\mathrm{ml}^{-1}$ are rare, except under bloom conditions. Consequently the inhibition we observed may be rare in nature.

\section{Gross growth efficiency and assessment of growth and grazing estimates}

GGE (GGE = yield, Fenchel 1987) is a measure of heterotrophic efficiency often required in numerical food web models. GGE is also a useful index for assessing the reliability of growth and grazing data. Straile (1997) reviewed the literature on GGE in a wide range of taxa, developed a multivariate model, and found that for many organisms GGE was positively correlated to food concentration at low food levels. This has also been observed specifically for oligotrich ciliates (Strombidium, Fenchel \& Jonsson 1988; tintinnids, Verity 1985).

If the functional response has a lower $x$-intercept than the numerical response, and the point of saturation is roughly the same for both responses (e.g. Figs. 2 $\& 4$ ), it follows that GGE will initially increase with food concentration (e.g. Fig. 5). Surprisingly, some studies on planktonic ciliates have not found that GGE increases with food concentration, at low levels (e.g. Jonsson 1986, Verity 1991). However, Jonsson (1986) examined a ciliate population under transient conditions over several generations, estimating GGE following the method of Fenchel (1982), while Verity (1991) did not include volume (or carbon) changes of ciliates with food concentration in his estimates ( $P$. Verity pers. comm.). Using transient conditions and ignoring volume changes may not be appropriate when determin- 
ing protozoan energetics, as the former may incorporate biases such as changes in the cell cycle (e.g. Fenchel \& Jonsson 1988, Ohman \& Snyder 1991), and the latter assumes a constant where one is lacking (e.g. Jakobsen \& Hansen 1997, Fig. 2).

We included volume changes and made measurements under steady-state conditions. However, our estimates of GGE at high food concentrations appear to be unrealistically high (Fig. 5). Measurements of $>0.7$ are rare (Straile 1997, Caron \& Goldman 1990) and levels of $>1$ are impossible, unless the organism is autotrophic. The reason(s) for this result are not clear, but we can suggest several possibilities.

It is possible that we used an incorrect carbon to volume (C:V) ratio for Strombidinopsis multiaurus, or that the $\mathrm{C}: \mathrm{V}$ is not constant. The $\mathrm{C}: \mathrm{V}$ may change with nutritional status: Ohman \& Snyder (1991) found that the carbon of Strombidium sp. increased by $0.022 \mathrm{pg}$ $\mu \mathrm{m}^{-3}$ when stationary and late exponential phase cells were compared, respectively. Under steady-state conditions, changes in cell volume and differential shrinkage of preserved cells collected from different food concentrations might also alter the $\mathrm{C}: \mathrm{V}$. We have used a constant ciliate $\mathrm{C}: \mathrm{V}$ of $0.19 \mathrm{pg} \mathrm{C} \mu \mathrm{m}^{-3}$ (Putt \& Stoecker 1989) to establish GGE (Fig. 5, solid line), but large protists may have a lower C:V (Strathmann 1967. Menden-Deuer \& Lessard unpubl.). It is also possible that larger, well-fed cells shrink less upon fixation and thus have a reduced $C: V$. Such unaccounted for changes would alter the GGE. For instance, if the $\mathrm{C}: \mathrm{V}$ of $S$. multiauris decreased linearly from 0.19 to $0.1 \mathrm{pg} \mathrm{C}$

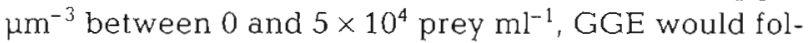
low the relationship depicted in Fig. 5 (dashed line). Clearly, investigations are needed to assess the effect of food concentration and cell volume on $C: V$.

It is also possible that our growth or grazing estimates are biased, and this altered the GGE. The growth measurements were determined over $48 \mathrm{~h}$ in the dark, while the grazing measurements were made over $0.5 \mathrm{~h}$ in low light. The ciliates in the grazing experiments had been cultured in the dark for $48 \mathrm{~h}$ before transfer into new food which had been grown in the light. It is possible that in the grazing experiments, the ciliates exhibited a short-term transient response to a light-induced, concentration-dependent, inhibitor produced by the dinoflagellate. If this was so, feeding inhibition would have been observed over the $0.5 \mathrm{~h}$ grazing incubation but not in the longer-term growth experiment in the dark. Alternatively, if inhibition observed in the grazing estimates is real, then it is surprising that a corresponding inhibition in growth was not observed. One explanation for this is that over the $48 \mathrm{~h}$ incubation, micropatches of food occurred within the culture wells. Such increased food levels would result in other less dense regions, where ciliates would be uninhibited by high food levels. If this is the case, we have overestimated growth at high food concentrations. However, micropatchiness may exist in the plankton, and therefore the feeding inhibition we predict at high food concentrations may rarely occur.

It could also be that manipulation during grazing experiments induced the grazing inhibition at high food concentrations. However, we have no reason to suspect this (manipulation was the same for all food concentrations), and inhibition has been shown to occur by others (see 'Grazing' above). Finally, it is possible that Strombidinopsis multiauris is mixotrophic, i.e. able to use prey chloroplasts to photosynthesise (Stoecker et al. 1987) or that prey continued to grow (or were not digested) after being ingested. However, the growth rate experiments were conducted at low light, and no choreotrichous ciliates (the group to which Strombidinopsis belongs) have been shown to be mixotrophic. If either of these phenomena occurred, they would provide an 'autotrophic' component to the growth rate, and would be more pronounced when ciliates were larger and 'full' with food. Such an 'autotrophic' growth rate would account for the GGE $>1$ at high food concentrations.

\section{Temperature response}

Temperature versus growth or volume relationships are sought both to understand underlying mechanisms and for predictive purposes. Growth rate can increase exponentially over the range where growth is positive (e.g. $Q_{10}$ relationships), but this relationship can also be linear (Cossins \& Bowler 1987). There is also considerable evidence that organism body size decreases with temperature (Atkinson 1994). Data from this study are insufficient to discuss the theoretical implications of these responses. However, we have examined these 2 relationships for Strombidinopsis multiauris to provide predictive parameters for food web models.

As might be expected, growth rate of Strombidinopsis multiauris increased with temperature, and mortality occurred at low and high temperatures. However, an exponential increase in growth rate did not occur over any temperature range (Table 2); consequently an estimate of $Q_{10}$ was not determined. The linear increase in growth rate over a range of $\sim 10^{\circ} \mathrm{C}$ (Fig. 6) agrees with work on other oligotrichs and other planktonic ciliates (Table 2). Of the regressions listed in Table 2, only the data from Urotricha furcata (Müller \& Geller 1993) show a significant exponential response (but note that data by Weisse \& Montagnes [1998] for $U$. furcata had a linear response). The average slope obtained from linear relationships presented in Table 2 was $0.072 \pm 0.021$ (SD) (omitting the data from Ras- 
soulzadegan 1982, which indicated no temperature effect on growth rate).

Although we have not conducted an exhaustive literature search, these data (Table 2) suggest that predictive estimates of growth versus temperature for individual taxa follow a linear rather than exponential relationship, and the slope of this line is $\sim 0.072 \pm 0.021$ (SD) $\mu{ }^{\circ} \mathrm{C}^{-1}$. These findings are in contrast to formulae that predict 'generalised ciliate' growth at ambient temperatures (e.g. Müller \& Geller 1993, Montagnes 1996). Such formulae, which combine many taxa, typically assume that growth rate exponentially increases with temperature; this may be so for interspecific estimates, but our analysis suggests that for intraspecific estimates a linear conversion is more appropriate.

The importance of cell volume changes has becn outlined above. Cell size decreases with increasing temperature for many organisms, including protists, and this appears to be the case for Strombidinopsis multiauris over much of its viable temperature range. However, at low temperatures there is a reverse of this trend (Fig. 7). With the limited data collected on changes in ciliate size with temperature, we are unable to speculate why this occurred or if it is a common phenomenon. Again, more detailed investigations seem warranted, and it is clear that such volume changes will need to be accounted for in models that involve temperature changes.

\section{Bloom dynamics}

The phytoplankton-ciliate blooms we have considered are mono-specific, rapid increases in numbers that are visible as transient peaks in abundance (cf. Legendre 1990, Lynn \& Montagnes 1991). In coastal waters, short-term phytoplankton blooms can be stimulated by a number of factors: tidal or wind mixing events, changes in irradiance, or nutrient inputs from terrestrial run off (Mackas et al. 1985, Harris 1986, Legendre 1990). Such blooms usually exist for $<20 \mathrm{~d}$, as mixing processes (e.g. wind and tides) dissipate them, and mesozooplankton populations respond if blooms persist. These short-term blooms may be composed of toxic or nuisance phytoplankton (e.g. toxic dinoflagellates or Phaeocystis), but equally may be composed of prey that are beneficial to higher trophic levels.

For the model, we assumed that over a $20 \mathrm{~d}$ period, phytoplankton blooms are not influenced by advection of organisms and nutrients in or out of the system. This is a simplification, but it allows an exploration of the potential for ciliate blooms to occur and an investigation of the duration and magnitude of these blooms. Furthermore, Montagnes (1993) indicated that when copepods are abundant $\left(>1 \mathrm{I}^{-1}\right)$ they can reduce ciliate populations and thus suppress ciliate blooms. Ciliate blooms were also suppressed when copepods were abundant in our model (data not shown), and we have focused on conditions where mesozooplankton are at a low abundance $\left(0.1 \mathrm{l}^{-1}\right)$, and ciliate blooms might have a maximum impact.

Blooms with the parameters described above are probably a few metres to hundreds of metres in size and are referred to as 'fine-scale patches' (Haury et al. 1978); these patches likely persist for 1 to $10 \mathrm{~d}$ and are dominated by episodic predation stress (Mackas et al. 1985). The model results (Fig. 8) indicate that Strombidinopsis multiauris will form bloorns which last on the order of $10 \mathrm{~d}$ when prey become abundant, due to rapid population growth. Furthermore, the model suggests that blooms under certain conditions ran produce. 35 ciliates $\mathrm{ml}^{-1}$. Thus, we have provided some limits to the duration and magnitude of these blooms.

Strombidinopsis sp. can be associated with and consume the red-tide dinoflagellate Gymnodinium sanguineum, when this prey is abundant (Jeong et al. 1999). The only other reports of Strombidinopsis associated with phytoplankton blooms suggest that it may be a link in the food chain between the nuisance phytoplankton Phaeocystis and zooplankton, and at times may even be partially responsible for the decline of blooms (Hansen et al. 1993, Hansen 1995). However, Hansen et al. (1993) suggested that copepod grazing on ciliates reduces the impact of ciliates on the Phaeocystis-ciliate-copepod food chain, and observations of planktonic ciliates in such blooms (Boekel et al. 1992) indicate abundances on the order of 10 ciliates $\mathrm{ml}^{-1}$ (estimated from biomass data using standard conversions and approximate estimates of size) and ciliate bloom durations of 20 to $30 \mathrm{~d}$. Thus, the type of Strombidinopsis bloom simulated in our model has not been observed in the field.

Rather than pertaining to Strombidinopsis specifically, our simulation may suggest how large $(\sim 100 \mu \mathrm{m})$ oligotrich ciliates can behave in the plankton. Primarily due to their conspicuous nature, reports exist on surface accumulations of planktonic ciliates (e.g. Dale \& Dahl 1987, Reid 1987, Montagnes \& Humphrey 1998). These accumulations may be produced from a combination of ciliate growth and concentration by physical processes (Dale \& Dahl 1987), and ciliate densities can be an order of magnitude higher than those predicted by our model. High abundances of ciliates have also been reported in snapshot observations of sub-surface waters, and such levels may be on the order of 20 to 50 cells $\mathrm{ml}^{-1}$ (e.g. Montagnes et al. 1999). However, there are few reports of the rise and decline of in situ ciliate blooms. The absence of such data may be due to the rarity of blooms, but may equall.y result from their transient nature, both in time and space. 
Our data suggest that under conditions where small phytoplankton are stimulated to grow at near maximal rates $\left(\mu=0.65 \mathrm{~d}^{-1}\right)$ and predation by mesozooplankton is low, large ciliates may respond over periods of $10 \mathrm{~d}$, bloom and then decrease in numbers due to starvation (Fig. 8), rather than by copepod predation (Fig. 9). The ecological implications of these blooms are discussed elsewhere (Montagnes 1993, 1996), but we can ask where might these blooms occur? Fine-scale blooms of ciliates have been reported for enclosed bays (Andersen \& Sorensen 1986) and in enclosures (Smetacek 1984, Suzuki \& Taniguchi 1993), but they may also occur in subsurface waters. For instance, the subsurface chlorophyll maximum, persistent in many marine and freshwater systems, may be an ideal location for such blooms to occur, and frontal zones have for some time been recognised to produce conditions which support algal blooms that ciliates could then exploit (e.g. Simpson et al. 1979).

It has long been recognised that fine-scale patchiness $(10$ to $100 \mathrm{~m}$ ) which may persist on the order of $10 \mathrm{~d}$ is an important component of plankton dynamics (Haury et al. 1978, Giller et al. 1994). However, most models of coastal planktonic ecosystems continue to examine processes on scales of weeks to months. If ciliates are an important component of these systems, as data on their abundance and biomass suggest (Lynn \& Montagnes 1991, Pierce \& Turner 1992), and if these ciliates act in a fashion indicated by the above model, then it would be prudent to revise the time scales of coastal plankton models and sampling regimes, to include these episodic events.

Acknowledgements. We thank M. Martin and K. McKinsey for help with collecting samples and M. Foy for technical assistance. We thank C. Walters for examining an initial version of the model used to explore predator-prey dynamics. We thank H.J. Jeong, T Weisse, S. Kimmance, and D. Franklin, and 2 anonymous reviewers for their comments on the manuscript. This work was partially funded by Natural Science and Engineering Research Council (NSERC) graduate and postdoctoral fellowships awarded to D.J.S.M. and an NSF grant, OCE 9403426, awarded to E.J.L.

\section{LITERATURE CITED}

A.elion CM, Chisholm SW (1985) Effect of temperature on growth and ingestion rates of Favella sp. J Plankton Res 7:821-830

Andersen P, Sørensen HM (1986) Population dynamics and trophic coupling in pelagic microorganisms in eutrophic coastal waters. Mar Ecol Prog Ser 33:99-109

Atkinson D (1994) Temperature and organism size - a biological law for ectotherms? Adv Ecol Res 25:1-58

Balczon JM, Pratt JR (1995) A comparison of methods for estimating short-term feeding rates of algivorous ciliated protozoa. Arch Protistenkd 146:49-58
Berges JA, Montagnes DJS, Hurd CL, Harrison PJ (1994) Fitting ecological and physiological data to rectangular hyperbolae: a comparison of methods using Monte Carlo simulations. Mar Ecol Prog Ser 114:175-183

Boekel WHM, Hansen FC, Riegman R, Bak RPM (1992) Lysisinduced decline of a Phaeocystis spring bloom and coupling with the microbial foodweb. Mar Ecol Prog Ser 81. 269-276

Buskey EJ, Hyatt CJ (1995) Effects of the Texas (USA) 'brown tide' alga on planktonic grazers. Mar Ecol Prog Ser 126: 285-292

Buskey EJ, Stoecker DK (1989) Behavioral responses of the marine tintinnid Favella sp. to phytoplankton: influence of chemical, mechanical and photic stimuli. J Exp Mar Biol Ecol 132:1-16

Caron DA, Goldman JC (1990) Protozoan nutrition regeneration. In: Capriulo GM (ed) Ecology of marine protozoa. Oxford Univ Press, Oxford, p 283-306

Cossins AR, Bowler K (1987) Temperature biology of animals. Chapman and Hall, London

Dale T, Dahl E (1987) Mass occurrence of planktonic oligotrichous ciliates in a bay in southern Norway, J Plankton Res 9:871-879

Fenchel T (1982) Ecology of heterotrophic microflagellates. II. Bioenergetics and growth. Mar Ecol Prog Ser 8:225-231

Fenchel T (1986) Protozoan filter feeding. In: Corliss JO, Patterson DJ (eds) Progress in protistology, Vol 1. Biopress Ltd, Bristol, p 66-113

Fenchel T (1987) Ecology of Protozod. Springer-Verlag, Berlin, p 197

Fenchel T, Jonsson PR (1988) The functional biology of Strombidium sulcatum, a marine oligotrich ciliate (Ciliophora, Oligotrichina). Mar Ecol Prog Ser 48:1-15

Frost BW (1972) Effects of size and concentration of food particles on the feeding behavior of the marine planktonic copepod Calanus pacificus. Limnol Oceanogr 17:805-815

Giller PS, Hildrew AG, Raffaelli DG (1994) Aquatic ecology, scale, pattern and process. Blackwell Scientific Ltd, London

Guillard RRL (1975) Culture of phytoplankton for feeding marine invertebrates. In: Smithe WL, Chaney $\mathrm{MH}$ (eds) Culture of marine invertebrate animals. Plenum Press, New York

Hansen FC (1995) Trophic interactions between zooplankton and Phaeocystis of globosa. Helgol Meeresunters 49: 283-293

Hansen FC, Reckermann M, Klein Breteler WCM, Riegman R (1993) Phaeocystis blooming enhanced by copepod predation on protozoa: evidence from incubation experiments. Mar Ecol Prog Ser 102:51-57

Hansen PJ, Bjornsen PK, Hansen BW (1997) Zooplankton grazing and growth: scaling within the 2-2,000- $\mu \mathrm{mm}$ body size range. Limnol Oceanogr 42:687-704

Harris GP (1986) Phytoplankton ecology, structure, function and fluctuation. Chapman and Hall, London

Haury LR, McGowan JA, Wiebe PH (1978) Patterns and processes in the time-space scales of plankton distributions In: Steele JH (ed) Spatial patterns in plankton communities. Plenum Press, New York, p 277-327

Heinbokel JF (1978) Studies on the functional role of tintinnids in the southern California Bight. I. Grazing and growth rates in laboratory cultures. Mar Biol 4:177-189

Jakobsen HH, Hansen PJ (1997) Prey size selection, grazing and growth response of the small heterotrophic dinoflagellate Gymnodinium sp. and the ciliate Balanion comatum-a comparative study. Mar Ecol Prog Ser 158: $75-86$ 
Jeong HJ, Shim JH, Lee CW, Kim JS, Koh SM (1999) Growth and grazing rates of the marine planktonic ciliate Strombidinopsis sp. on red-tide and toxic dinoflagellates. J Eukaryot Microbiol 46:69-76

Jerome CA, Montagnes DJS, Taylor FJR (1993) The effect of the quantitative protargol stain and Lugol's and Bouin's fixatives on cell size: a more accurate estimate of ciliate species biomass. J Eukaryot Microbiol 40:254-259

Jonsson PR (1986) Particle size selection, feeding rates and growth dynamics of marine planktonic oligotrichous ciliates (Ciliophora: Oligotrichina). Mar Ecol Prog Ser 33: 265-277

Landry MR (1994) Methods and controls for measuring the grazing impact of planktonic protists. Mar Microb Food Webs 8:37-57

Legendre L (1990) The significance of microalgal blooms for fisheries and for the export of particulate organic carbon in the oceans. J Plankton Res 12:681-699

Lessard EJ (1993) Culturing free-living marine phagotrophic dinoflagellates. In Kemp PF, Sherr BF, Sherr EB, Cole JJ (eds) Handbook of methods in aquatic microbial ecology. Lewis Publishers, Boca Raton, FL, p 67-75

Lynn DH, Montagnes DJS (1991) Global production of heterotrophic marine planktonic ciliates. In: Reid PC, Turley $\mathrm{CM}$ Burkill PH (eds) Protozoa and their role in marine processes. NATO ASI publication Series G, Vol 25. Springer Verlag, Berlin, p 281-307

Lynn DH, Montagnes DJS, Dale T, Gilron GL, Strom SL (1991) A reassessment of the genus Strombidinopsis (Ciliophora, Choreotrichida) with descriptions of four new planktonic species and remarks on its taxonomy and phylogeny. J Mar Biol Assoc UK 71:597-612

Mackas DL, Denman KL, Abbott MR (1985) Plankton patchiness: biology in the physical vernacular. Bull Mar Sci 37 $652-674$

Martinez EA (1983) Effects of temperature and food concentration on competitive interaction in three species of marine Ciliophora. Carib J Sci 19:1-7

Montagnes DJS (1993) An investigation of the growth and feeding responses of oligotrich ciliates to food types and concentrations: an approach to assessing the potential of marine planktonic ciliate blooms. PhD thesis Univ British Columbia, Vancouver

Montagnes DJS (1996) Growth responses of planktonic ciliates in the genera Strobilidium and Strombidium. Mar Ecol Prog Ser 130:241-254

Montagnes DJS, Humphrey E (1998) A description of occurrence and morphology of a new species of red-water forming Strombidium (Spirotrichea, Oligotrichia). J Eukaryot Microbiol 45:502-506

Montagnes DJS, Lynn DH, Roff JC, Taylor WD (1988) The annual cycle of heterotrophic planktonic ciliates in the waters surrounding the Isles of Shoals, Gulf of Maine: an assessment of their trophic role. Mar Biol 99:21-30

Montagnes DJS, Berges JA, Harrison PJ, Taylor FJR (1994) Estimating carbon, nitrogen, protein, and chlorophyll a from volume in marine phytoplankton. Limnol Oceanogr 39:1044-1060

Montagnes DJS, Berger JD, Taylor FJR (1996) Growth rate of the marine planktonic ciliate Strombidinopsis cheshiri Snyder and Ohman as a function of food concentration and intercloral variability. J Exp Mar Biol Ecol 206 : $121-132$

Montagnes DJS, Poulton AJ, Shammon TM (1999) Mesoscale, finescale and microscale distribution of micro- and nanoplankton in the Irish Sea, with emphasis on ciliates and their prey. Mar Biol 134:167-179
Müller H, Geller W (1993) Maximum growth rates of aquatic ciliated protozoa: the dependence on body size and temperature reconsidered. Arch Hydrobiol 126:315-327

Nielsen TG, Kiørboe T (1994) Regulation of zooplankton biomass and production in a temperate, coastal ecosystem. 2. ciliates. Limnol Oceanogr 39:508-519

Nielsen TG, Løkkegaard $B$, Richardson $K$, Pedersen FB, Hansen L (1993) Structure of plankton communities in the Dogger Bank area (North Sea) during a stratified situation. Mar Ecol Prog Ser 95:115-131

Ohman MD, Snyder RA (1991) Growth kinetics of the omnivorous oligotrich ciliate Strombidium sp. Limnol Oceanogr 36:922-935

Pace ML, Bailiff MD (1987) Evaluation of a fluorescent microsphere technique for measuring grazing rates of phagotrophic microorganisms. Mar Ecol Prog Ser 40: 185-193

Pierce RW, Turner JT (1992) Ecology of planktonic ciliates in marine food webs. Rev Aquat Sci 6:139-181

Putt M (1991) Development and evaluation of tracer particles for use in microzooplankton herbivory studies. Mar Ecol Prog Ser 77:27-37

Putt M, Stoecker DK (1989) An experimentally determined carbon:volume ratio for marine 'oligotrichous' ciliates from estuarine and coastal waters. Limnol Oceanogr 34: 333-355

Rassoulzadegan F (1982) Dependence of grazing rate, gross growth efficiency and food size range on temperature in a pelagic oligotrichous ciliate Lohmanniella spiralis Leeg., fed on naturally occurring particulate matter. Ann Inst Océanogr 58:177-184

Rassoulzadegan F, Laval-Peuto M, Sheldon RW (1988) Partitioning of the food ration of marine ciliates between picoand nanoplankton. Hydrobiologia 159:75-88

Reid PC (1987) Mass encystment of a planktonic oligotrich ciliate. Mar Biol 95:221-230

Sherr EB, Sherr BF (1993) Protistan grazing rates via uptake of fluorescently labeled prey. In: Kemp PF, Sherr BF, Sherr EB, Cole JJ (eds) Handbook of methods in aquatic microbial ecology. Lewis Publishers, Boca Raton, FL, p 695-701

Simpson JH, Edelsten DJ, Edwards A, Morris NCG, Tett PB (1979) The Islay front: physical structure and phytoplankton distribution. Estuar Coast Mar Sci 9:713-726

Smetacek V (1981) The anmual cycle of protozooplankton in Kiel Bight. Mar Biol 63:1-11

Smetacek V (1984) Growth dynamics of a common Baltic protozooplankter: the ciliate genus Lohmanniella. Limnologica 15:371-376

Spain JD (1982) BASIC microcomputer models in biology. Addison-Wesley Publishing $\mathrm{Co}_{\text {, London }}$

Stoecker DK, Cucci TL, Hulburt EM, Yentsch CM (1986) Selective feeding by Balanion sp. (Ciliata: Balanionidae) on phytoplankton that best support its growth. J Exp Mar Biol Ecol 95:113-130

Stoecker DK, Michaels AE, Davis LH (1987) Large proportion of marine planktonic ciliates found to contain functional chloroplasts. Nature 326:790-792

Straile D (1997) Gross growth efficiencies of protozoan and metazoan zooplankton and their dependence on food concentration, predator-prey weight ratio, and taxonomic group. Limnol Oceanogr 42:1375-1385

Strathmann RR (1967) Estimating the organic carbon content of phytoplankton from cell volume or plasma volume. Limnol Oceanogr 12:411-418

Suzuki T, Taniguchi A (1993) Successional sequence of ciliates in surface water after a pulsed addition of deep water. Bull Plankton Soc Jpn 40:27-39

Tiselius P, Jonsson PR, Verity PG (1993) A model evaluation of 
the impact of food patchiness on foraging strategy and predation risk in zooplankton. Bull Mar Sci 53:247-264

Verity PG (1985) Grazing, respiration, excretion, and growth rates of tintinnids. Limnol Oceanogr 30:1268-1282

Verity PG (1991) Measurement and simulation of prey uptake by marine planktonic ciliates fed plastidic and aplastidic nanoplankton. Limnol Oceanogr 36:729-750

Weisse T, Montagnes DJS (1998) Effect of temperature on inter- and intraspecific isolates on Urotrichia (Prostomatida, Ciliophora). Aquat Microb Ecol 15:285-291

Welschmeyer NA, Lorenzen CJ (1984) Carbon-14 labeling of

Editorial responsibility: Tom Fenchel,

Helsinger, Denmark phytoplankton carbon and chlorophyll a carbon: determination of specific growth rates. Limnol Oceanogr 29: 135-45

Winter FDe, Persoone G (1975) Preliminary experiments with the ciliate Fabrea salina as a potential live food for mariculture purposes. In: Persoone G, Jaspers E (eds) Research in mariculture at laboratory-and pilot-5cale, Vol 1 Proc 10th Eur Mar Biol Symp Ostend, Belgium, 17-23 September, 1975. Universa Press, Wetteren, p 37-48

Zar JH I (1984) Biostatistical analysis. Prentice-Hall Inc, Englewood Cliffs, NJ

Submitted: May 25, 1999; Accepted: October 5, 1999

Proofs received from author(s): December 7, 1999 